\title{
Photodimerization in substituted di- and oligopeptides by UV-light for optical data storage
}

Lohse, Brian; Ramanujam, P.S.; Hvilsted, Søren; Berg, R.H.

Publication date:

2005

Document Version

Publisher's PDF, also known as Version of record

Link back to DTU Orbit

Citation (APA):

Lohse, B., Ramanujam, P. S., Hvilsted, S., \& Berg, R. H. (2005). Photodimerization in substituted di- and oligopeptides by UV-light for optical data storage. Poster session presented at 19th American Peptide Symposium, San Diego, California, United States.

\section{General rights}

Copyright and moral rights for the publications made accessible in the public portal are retained by the authors and/or other copyright owners and it is a condition of accessing publications that users recognise and abide by the legal requirements associated with these rights.

- Users may download and print one copy of any publication from the public portal for the purpose of private study or research.

- You may not further distribute the material or use it for any profit-making activity or commercial gain

- You may freely distribute the URL identifying the publication in the public portal

If you believe that this document breaches copyright please contact us providing details, and we will remove access to the work immediately and investigate your claim 


\title{
Photodimerization in substituted di- and oligopeptides by UV-light for optical data storage
}

\author{
Brian Lohse ${ }^{a}$, P.S. Ramanujam ${ }^{b}$, Søren Hvilsted ${ }^{c}$ and Rolf H. Berga,* \\ a Polymer Department, Risø National Laboratory, DK-4000 Roskilde, Denmark \\ ${ }^{b}$ Department of Optics and Plasma Research, Risø National Laboratory, DK-4000 Roskilde, Denmark \\ ${ }^{c}$ Danish Polymer Centre, Department of Chemical Engineering, Technical University of Denmark, DK-2800 Kgs. Lyngby, Denmark
}

\begin{abstract}
Photodimerization in pyrimidine-substituted di- and oligopeptides, was investigated with a view to their application as new materials for optical data storage. The effects of variations in the amino acid sequence, the spacer and substituent effects on the chromophores were investigated. Three of the synthesized compounds were identified as possible media for optical data storage.
\end{abstract}

\section{Objectives}

To develop a film of pyrimidine-substituted peptides, possessing five important criteria for digital optical storage:

\section{Large contrast between irradiated and non- irradiated areas of the medium (dimerization efficiency).}

\section{Fast response for recording}

3. Stable during storage $\left(-30^{\circ} \mathrm{C}\right.$ and $\left.50^{\circ} \mathrm{C}\right)$

4. Good optical and mechanical properties

5. Cheap large scale production.

\section{Introduction}

DNA is the ultimate data storage molecule, storing in four bases the information to make proteins and, essentially, life. The photodimerization of thymine, discovered long ago upon UV irradiation, is one of the most important reactions in photobiology. It is highly probable that dimerization in irradiated DNA constitutes one of the essential factors responsible for the sensitivity of nucleic acids and cells to the effects of UV-light. The dimerization takes place through the C5-C6 double bond of the pyrimidine and involves the formation of a cyclobutane ring, as shown in the figure below. Here we describe chromophores attached to a peptide backbone, where the storage of data can be achieved through the principle of photodimerization of neighboring chromophores undergoing $(2 \pi+2 \pi)$ cycloaddition, first in solution $\left(\mathrm{H}_{2} \mathrm{O}\right)$, and then as a film applied onto a quartz plate, if good dimerization efficiency was observed.

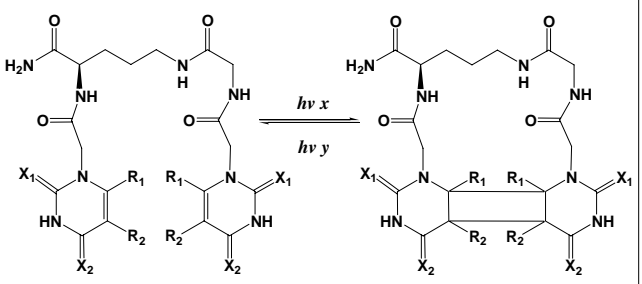

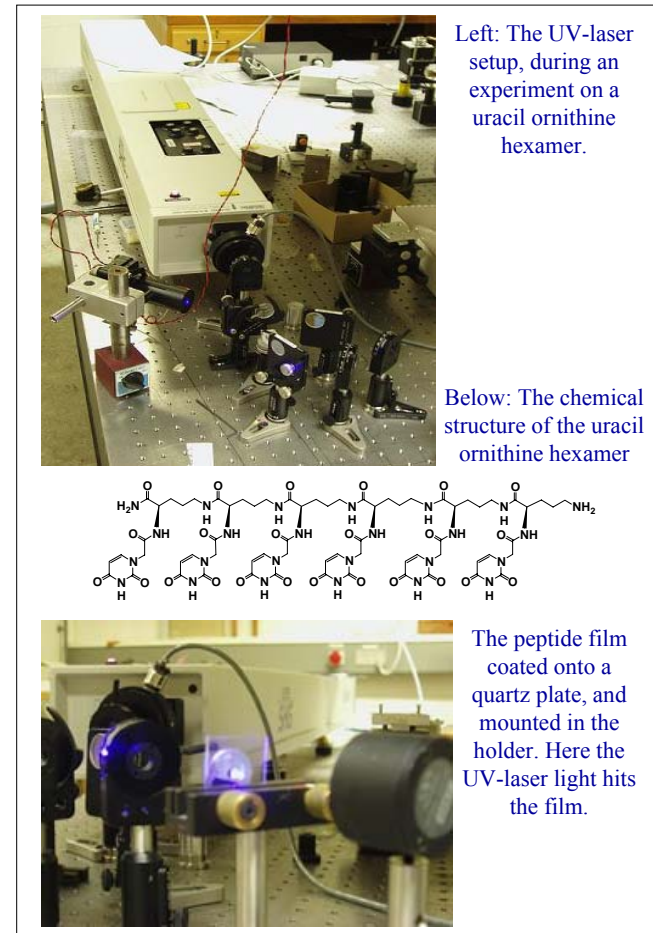

Experimental

The peptides were synthesized using the stepwise Merrifield SPPS method. The chromophores were synthesized using standard organic chemistry. The compounds were first tested in solution, and irradiated under a UV-lamp for 15, 30 and $60 \mathrm{~min}$. If good dimerization efficiency was observed, the compound was prepared as a film and tested in our UV-laser setup, in order to test how fast the compound could reach maximum transmission.

Results
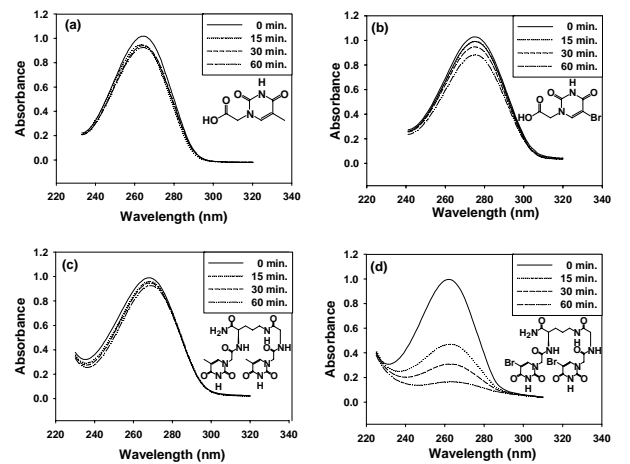

Absorption spectra of (a) thymine 1-acetic acid and (b) 5-bromouracil 1-acetic acid compared with the corresponding pyrimidine-substituted dipeptides (c) $N^{\alpha}, N^{\alpha^{\prime}}$-bis-(thymine-1ylacetyl)-( $N^{\varepsilon}$-glycylornithine amide) and (d) $N^{\alpha}, N^{\alpha^{\prime}}$-bis(bromouracil-1-ylacetyl)-( $N^{\varepsilon}$-glycyl-ornithine-amide), all in water, at different irradiation times.

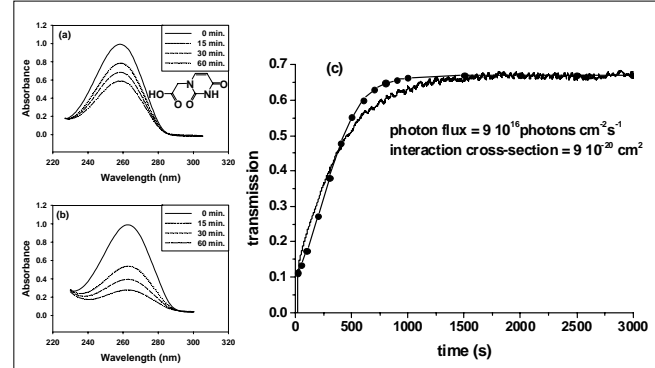

Experimentally measured absorption of (a) Uracil 1-acetic acid and (b) uracil ornithine hexamer in solution. Trans-

mission through a thin film of uracil ornithine hexamer (c).

\section{Conclusion}

Overall we observed a significant increase in dimerization efficiency when going from a free chromophore in solution to a chromophore attached to a peptide. Furthermore the peptide films had good optical and mechanical properties, and were completely stable. Good correlation was found between solution and film, making solution testing an effective screening method. Finally, the peptides are environmentally safe and suitable for upgrade to large scale.

Perspectives

This new material for optical data storage using UVlaser, instead of red and Blu-ray, is a step towards the next generation. Bit storage at $257 \mathrm{~nm}$ can give a storage capacity of over 60 Gbytes compared to the latest Blu-Ray discs, and a further three fold increase in capacity can be achieved with multilevel storage. It is believed that a UV-diode laser will be on the market in ten years, and hopefully

we will have been able to

obtain a fully optimized

material using peptides,

which may store up to 1

terabyte on a conventional $\operatorname{disc}(12 \mathrm{~cm})$.

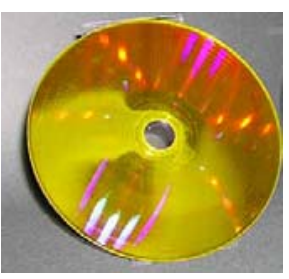

A possible future technology, the Peptide Versatile Disc (PVD), as a conventional sized DVD.

\section{References}

B. Lohse et al., Photodimerization in pyrimidinesubstituted dipeptides, J.Pep. Sci. , 2005, in print

B. Lohse et al., Photodimerization in uracil and 5bromouracil substituted di- and oligopeptides, J.Pep.Sci., 2005, submitted

B. Lohse et al., Cycloaddition in peptides for high capacity optical storage, J.J.A.P., 2006, submitted

P.S.Ramanujam et al., Photodimerization in dipeptides for high capacity optical digital storage, Appl.Phys.Lett., 2004, 85, 1665-1667

Further information

rolf.berg@risoe.dk

www.brianlohse.dk 